\title{
Development of Customs Fiscal Function in Latvia
}

\author{
Normunds Rudzītis ${ }^{1}$, Aldis Čevers ${ }^{1},{ }^{1}$ Riga Technical University
}

\begin{abstract}
Globalization of the world economy and increased international trade in economic development of countries seriously affect Customs Services and changes customs functions. Moreover, the measurement efficiency and effectiveness of Customs Services are determined based on an accurate identification of the customs functions to be performed and on the basis of the amount of dynamic analysis. The article shows that significant reduction of the customs fiscal function is identified in the period when Latvia joined the EU Customs Union. The reduction took place due to the country's efforts to improve business environment and strengthen the competitiveness of enterprises, as well as to improve tax administration system.
\end{abstract}

Keywords - Customs functions, excise tax, measurement of customs performance, value added tax.

\section{INTRODUCTION}

Globalization of the world economy and the increase of international trading influence on the economic development of countries are some of the principal external environment factors that increase ambiguity in the operation of customs services. A results-oriented operation of state governance sets forth an obligation for customs authorities to assess the usefulness and efficacy of their operations. In order to do so, one must understand the functions to be implemented by the customs services, as well as the trends in the change of external environment and the influence thereof on the goals and operational results of customs. Significant changes in the operation of customs were brought by the accession of Latvia into the EU Customs Union. As a result of this event from 2005 onwards the external environment for the operation of customs was subject to a rapid change which in turn caused changes in the performance results of customs including the performance of customs fiscal function.

The general fiscal policy of a state is one of the cornerstones in the stability of national macro economy. Thus, one of the principal elements in the fiscal policy is the state income ( $\operatorname{tax})$ policy. Traditionally, customs institutions are authorised to administrate indirect tax set by the state that must be paid for importing goods from the countries that are not the EU member states. The responsibility of Customs Board of the State Revenue Service (hereinafter - Customs Service) to a full extent of competency includes administration of customs duty, administration of value added tax (hereinafter VAT) and excise tax in the part that relates to the flow of goods within the framework of the Community and 3rd Countries. Since customs duty in the national economy with the help of fiscal instruments implements international trade facilitation and, simultaneously, internal market protection functions, the implementation of the fiscal function is ensured by the Customs Service by applying and collecting value added and excise tax.

In literature the results of customs services and challenges in the provision of national income are discussed in great detail, however, this analysis is aimed at the provision of collection of an in-depth customs tax and similar payments. The World Customs Organisation (WCO) hosts annual Revenue Management Conferences which mainly review the aspects of customs duty collection. And so in the Conference of 2014, the emphasis was put on the improvement of customs duty administration. The conference discussed the role of customs in the implementation of fiscal function of a state by analysing cases of various states in giving the customs service the responsibility of not only administrating indirect tax but also other duties and payments. In the meantime, the aspects of tax fraud prevention were reviewed by putting a significant emphasis on the influence on VAT administration. D. Adomaviciute (2013) in the study on the role of Lithuanian customs in the performance of the national budget indicates that the proportion of the tax collected by Lithuanian customs (both in terms of customs payments, as well as in VAT and excise tax) in the performance of the aggregate budget of Lithuania is considered to be important because, for example, in 2012, it accounted for $28 \%$ of total national budget. However, D. Widdowson (2007) indicates that the role of customs worldwide changes due to the influence of globalisation factors as well as after the acts of terrorism on 9/11 in the US. T. Yasui (2014) points out that the extent of customs fiscal function implementation changes due to globalisation with a decreasing amount of collected customs duty as a result of the reduction of total tariffs as well as the expansion of the range of implementation of customs fiscal function upon administration of tax. D. Widdowson (2007) notes that while the fiscal function of customs remains important, the role of customs in the strengthening of public safety and promotion of trade is set to increase.

The goal of the paper is to show the most recent trends in the development of customs fiscal function in Latvia by identifying the principal underlying causes, as well as to perform a comparative analysis with the performance results from the customs services of the Baltic states.

The following methods were used in the course of the study: the analysis of scientific and practical literature, collection, classification, elaboration and summation of information.

\section{IDENTIFICATION OF CUSTOMS FUNCTION}

Customs affairs in their diversity constitute an integral part of supervision and management system for the international goods flow. All around the world, customs affairs is 
understood as a certain procedure according to which goods are moved across the customs border and subject to customs duty, customs formalities, customs control as well as other means aimed at the implementation of customs policy (Gulbis \& Cevers, 2010). Often upon speaking about moving goods across border, there is an evident difficulty to distinguish between the terms used in practice and on field - "customs legislation", "customs affairs", "customs policy", "customs rates and extra-rate regulation", etc. These terms must be viewed in the light of their content and in analysis of their various elements and constituents.

Upon studying the definition of the term "customs", it may be deducted that customs affairs encompass one of the state's function (Kosenko \& Oposhnyan, 2006).

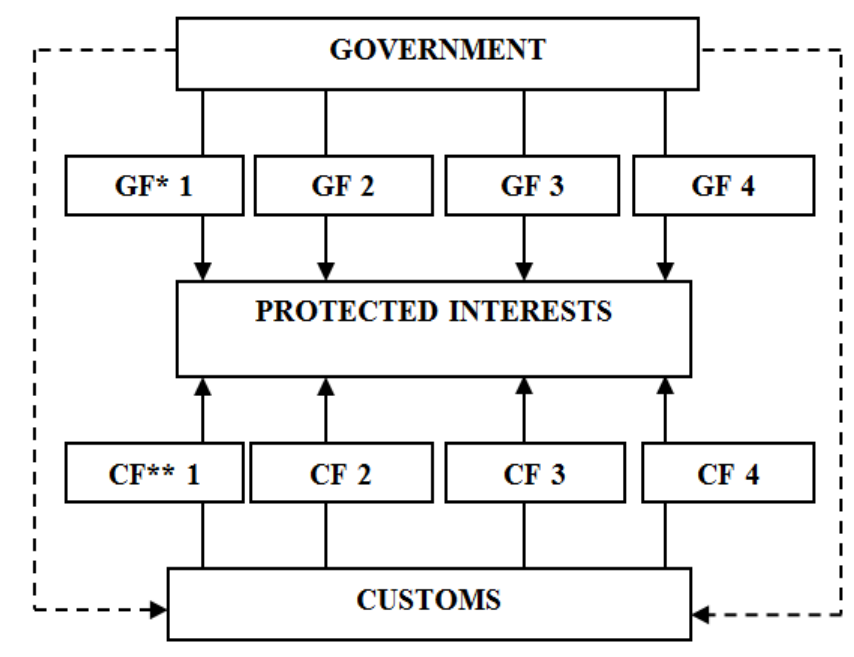

* GF-government functions; ** $\mathbf{C F}$-customs functions

Fig. 1. Interaction of Government and Customs service functions (Cevers, 2013).

In line with the definition by the outstanding Latvian law scholar K. Dislers - the function of state power is the legal operation of the state power authority in the performance of the legal task of the state (Dišlers, 2002). Thus it is only logical that within the country any matter of organisation, results and assessment of sate governance authorities is of sufficient importance. Among the functions of the state one may find those that are performed directly by customs authorities as well as the functions that the latter takes part in only indirectly.

Fig. 1 illustrates the link between the governmental functions, protected interests in society and customs operations.

The naming and definition of customs function is important for the formation of a comprehensive understanding of customs affairs. It must be taken into consideration that upon describing the operation of customs service of another state governance authority, such terms as strategic goals, mission, tasks, processes, etc. are often used. These terms may not be used without due consideration because it is not only important to define what is expected from the specific service, but also to perform a continuous supervision and regular assessment of the operational results as well as compliance with the requirements and the given conditions. L. de Wulf, J. B. Sokol (2004) and L. Michael (1998) in the development of customs modernisation handbook as well as in other papers link customs modernisation with an accurate definition of customs functions, while K. Michael (2003) links changes to the functions of customs with the necessary changes in the administration of customs.

The operation of customs in the light of modern economic and political integration is to be assessed in relation to the performance of the traditional function entrusted to it, with consideration of all relevant economic, social, political and legal aspects of today. One must consider the unique role of customs in the society because it operates both the service and the law enforcement authority, furthermore, it finds itself doing so in dynamically changing external environment. There are both fixed and dynamic aspects present in the operation of customs - fiscal function, market protection, combating smuggling of restricted goods complemented with less traditional functions, processes and methods, while the development is reflected in positive and negative matters simplification of procedures, opening of borders and free flow of goods are unavoidably followed by the rise of cross-border crime, fraud and other threats to the society.

In order not to mix the function with the task, for the customs function to comply with the general guidelines of the state and the legal theory, these may not be viewed in a general sense and the number thereof by definition may not be high. On the basis of the research on the understanding of customs definition worldwide, it may be concluded that the operation of customs is better described by the functions that may be separated and are necessary for the implementation of the needs and interests of the state:

- fiscal;

- facilitation of legal trade;

- provision of public security;

- internal market protection;

- statistical.

Each of the listed functions has its own content, place in the implementation of the state policy and compliance with the objectives of the state, as well as various tools of implementation. So, for example, the basis of the domestic market protection is implemented via customs rates and the use of other international trading buffers. Upon implementation of the protective function, customs perform also completely different actions, upon controlling the international trade of wild animals and plants, movement of counterfeit goods across the board and the import and export of items of cultural and artistic value. For the purposes of public safety, legal regulations for customs include restrictions of import for weapons and drug substances as well as restrictions for goods with strategic value. The facilitating function of legal trade is related to the improvement of customs control methods and process which would allow businesses to save time and costs upon moving goods across the border. Statistical (reporting) function is necessary for the application of domestic market protection and trading policy 
measures, as well as for the reporting of goods circulation in international trade.

To study the function of customs means to analyse the purpose of the term "customs affairs", its essence and content, as well as to explain what it should be. An incorrect approach to the term of customs function may lead to inaccurate and false conclusions. For example, as per legislation of the Russian Federation, customer performs more than 60 different functions; Russian scholars believe that the non-organisation of the use functions (non-structuring) prevents the correct understanding of customs affairs. S. Baramzin (2001) believes that customs functions may be directly viewed as an object of quality management, while V. Kosenko and L. Oposnan (2005) see customs function as the basis for efficacy assessment.

For better understanding of customs matters the following questions have to be answered:

- What are the primary and secondary functions;

- Why are customs authorities established;

- What is the purpose and objective of the operation thereof? (Kosenko \& Oposhnyan, 2006).

It is important that a number of different authorities, organisations, persons and unions are interested in the results of the operation of customs. They primarily see and assess the functions of customs that directly affect their operation and form their own opinion of customs assessment criteria. This context complicates an unbiased assessment of customs operation.

At an international level, the definition of customs functions and tasks may be found in the documents of international organisations (WCO, WTO, WB, IMF, ICC), as well as in international and regional agreements along with the customs union incorporating and supporting documentation. Very significant source that may indicate the modern tasks and functions of customs services are the regional customs affairs regulatory acts. In terms of the European region, it is the EU Customs Union Code [7].

Currently, the KIOTO Convention [8] is considered as the most important international multilateral agreement in the field of customs. While this document does not specify functions of customs, it sets forth tasks for customs to perform at an international scale.

The programme COLUMBUS (Programme for the assessment of customs operation and determination of needs) developed by World Customs Organisation - reflects understanding of the organisation about the functions and development trends of customs. It sets that the principal daily duties of the customs include timely collection of fees, reporting on income, providing recommendations about the guidelines of state trade and fiscal policy, facilitating the development of trade, protecting the public, providing accurate statistical information, creating professional and transparent administration which implements the best international practice and performs its duties in good faith, operates with increasing efficiency and quality, the basic functions of which are defined as follows:
- income collection and reporting;

- implementation of state trade and fiscal policy, provision of recommendations for the development thereof;

- facilitation of trade;

- protection of the state and public;

- provision of international supply chain security and performance of relevant international duties;

- provision of accurate statistical data;

Also at a national level, there are legal acts that either directly or indirectly indicate certain functions of customs. Such indications are found in customs codes and laws, customs service development documents, strategies and in the reviews on the results of customs operation.

It must be noted that customs affairs, while standardised to a certain degree worldwide, have acquired certain specifics due to various historical, political and economic conditions, by being influenced by various external factors and in accordance with various national and regional circumstances. It relates to both the functions and the importance and priorities of customs. It is interesting to see the development of fiscal function in Latvia due to it being within the European Union.

\section{DESCRIPTION OF CUSTOMS FISCAL FUNCTION}

In the period of time prior to Latvia's accession to the EU, the contribution of Customs Service in collection of VAT and excise tax was highly important. Customs authorities applied and collected around $75 \%$ of the total excise tax collected by the state (Fig. 3), while in administration of VAT, the average VAT applied by customs authorities was in excess of $5 \%$ from the total VAT collected by the state (Fig. 2). After the accession to the EU and from 2004 onwards the situation changed dramatically. The VAT applied and collected by Customs Service decreased by the amount that was paid for goods imported from the EU. Meanwhile it must be noted, that upon accession to the EU, Customs Union gave rise to the condition that the procedure for goods intended for the destination country under IM4200 may be cleared by customs in other EU member states and after that with a deferred VAT payment delivered to the destination country.

Thus the company using the opportunities of the Customs Union must not withhold significant amount of VAT, which would have been so before the accession to the EU, upon importing goods to the country from 3 rd countries.

This opportunity is becoming increasingly popular among companies, because one must consider that the freight costs, for example, for sea freight to Klaipeda and Liepaja are close to identical, however, the opportunity not to pay VAT immediately upon import of the goods but by settling it within 15 days after the end of taxation period is a significant saving of resources. Notwithstanding the above VAT payment solutions and the amount of VAT applied and collected had increased by $33 \%$ in the period of time from 2005 to 2007 and this may be explained by general growth of the national economy of the Republic of Latvia. 


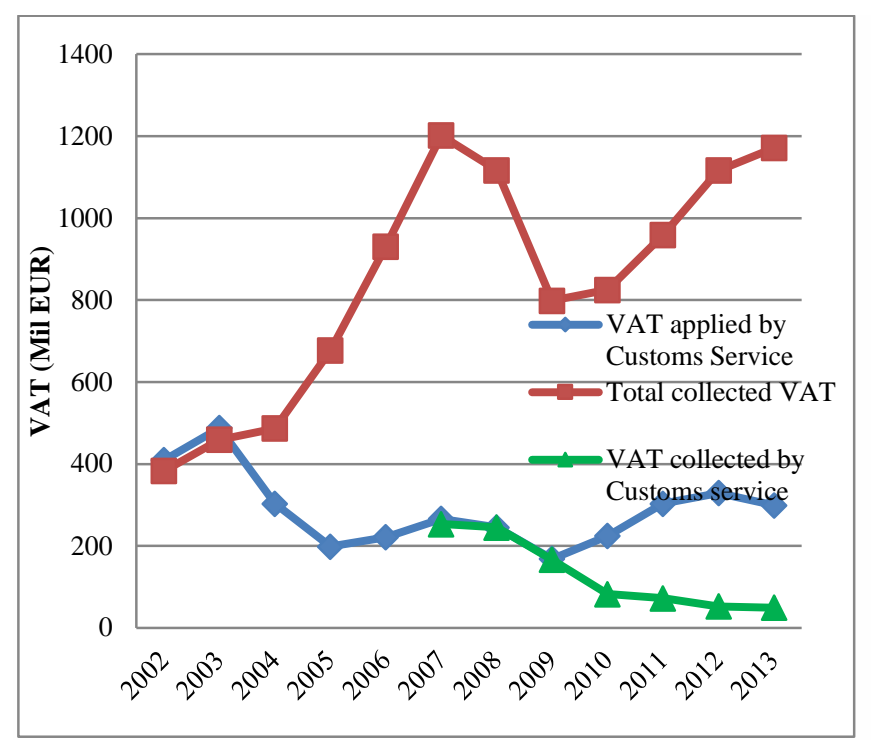

Fig. 2. VAT applied and collected by the Customs Service of Latvia.

Source: State Revenue Service. Statistics and performance results. 2013

After that, the period up till 2009 in terms of VAT administration was affected by the financial crises and in spite of the VAT rate increase the tax collection rates decreased by $38 \%$. As a result of applying the customs procedure IM4200, deferred VAT payments for goods intended for the destination country but cleared in another member state open an opportunity for fraud, the discovery of which involves not only coordinated actions and exchange of information between customs and tax administration authorities in many countries. The aforesaid along with the unequal situation with goods importers from the EU member states gave grounds for the amendments in the Law on VAT. As a result of these amendments, a person - VAT payer who has received the permit from the State Revenue Service may defer the VAT calculated in the customs declaration for the goods released in free circulation until it is included in the VAT declaration of the respective period. By introducing this regulation of choice of VAT application these amendments created the following benefits for both the tax payers and the tax administration authorities: 1) VAT administration is facilitated; 2) persons subject to tax are given the opportunity to reduce their administrative liability and costs; 3) VAT payment procedure into the state budget is made easier; 4) competitiveness and operational efficiency of persons subject to tax is increased.

Along with the benefits from 2009 onwards the VAT applied in customs offices increased (except in 2013), but the actual amount of VAT collected decreased reaching $37 \%$ in 2010 and $16.6 \%$ in 2013 from the VAT applied in Customs Service. The total contribution of VAT collected by Customs Service was only $4.3 \%$ of the total VAT collected by the state. Thus, upon operating in the framework of the EU Customs Union, the importance of Customs Service fiscal function in terms of VAT collection in the period of time from 2005 to 2013 had drastically decreased from $29.3 \%$ to $4.3 \%$. It must be noted that in 2013, the VAT applied by Customs Service was 299 mil EUR, which is up to $25.6 \%$ of the total VAT applied in the country. Similarly to the administration of VAT, the volume of excise tax application and collection upon accession of Latvia to the EU had been subject to sharp decline because Customs Service no longer administered the application of excise tax to excise goods imported from the EU states. Therefore, in 2013, the customs authorities applied only $31.8 \%$ of the total excise tax collected by the state as compared to $80 \%$ of the total state's excise tax applied and collected by customs offices in 2005 (see Fig. 3). After the accession to the EU Latvia was subject to the EU excise tax harmonisation principles which set forth inter alia unified excise goods circulation and tax payment conditions. Thus, if in the general procedure, the importer paid the excise tax for excise goods that are subject to customs procedure "releasing into free circulation" in the state budget prior application for the customs procedure at the customs offices, then for specially registered companies who declared excise goods upon delivery of the said to an excise goods warehouse by submitting a registered excise goods guarantee in line with the relevant procedure, the company might release the goods for free circulation while not paying excise tax (deferred mode).

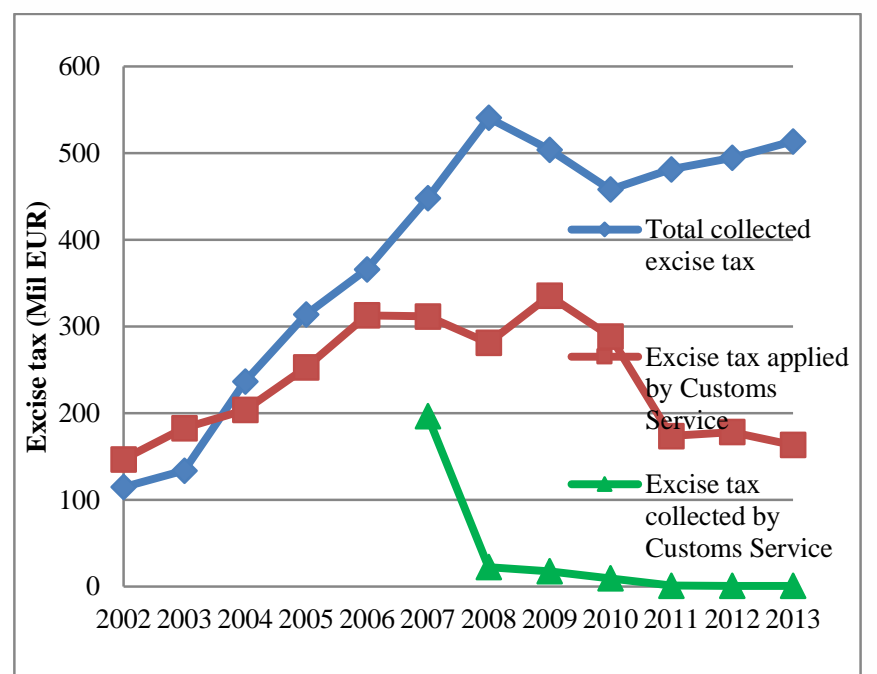

Fig. 3. Excise tax, applied and collected by the Customs Service of Latvia. Source: State Revenue Service. Statistics and performance results. 2013

In such a case the excise tax would be paid 15 days after the expiry of the tax period for the previous period in line with the conditions according to which the relevant company is in operation. Such approach facilitates business and reduces business costs in trade with excise goods. In the period of time from 2007 to 2013, the proportion of excise tax applied and collected by Customs Service by percentage decreased respectively from $63 \%$ to $0.7 \%$. Thus operating under the framework of the EU Customs Union, the importance of Customs Service's fiscal function in the collection of excise tax in the period of time from 2005 to 2013 sharply declined from $80 \%$ to $0.7 \%$; in the meantime it must be noted that in 2013, the excise tax applied by the customs services amounted to 163.5 mil EUR, which makes up to $31.8 \%$ of the excise tax applied in the country. 


\section{IMPLEMENTATION OF CUSTOMS FISCAL FUNCTION IN LITHUANIA AND ESTONIA}

The implementation of fiscal function by the Customs Services in Lithuania and Estonia similar to that in Latvia is ensured by performing the application of VAT and excise tax and collection for import of goods from 3rd countries.

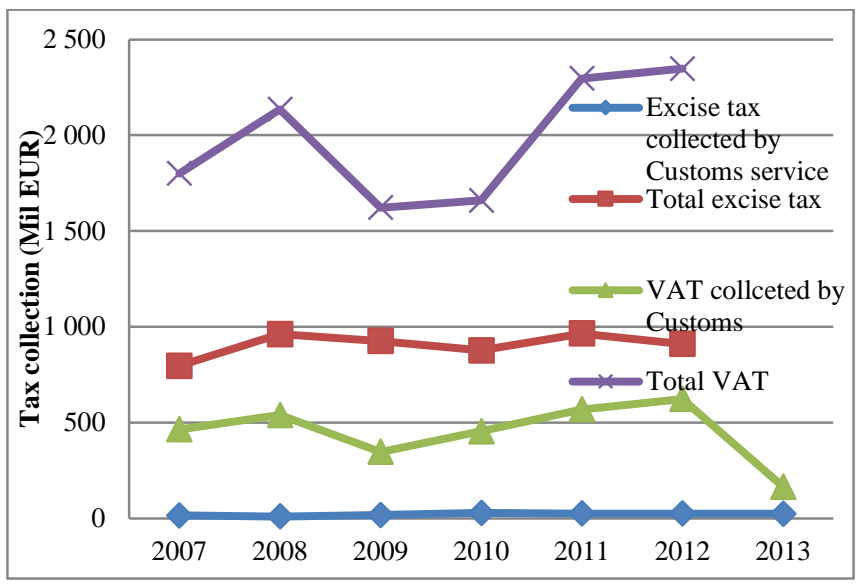

Fig. 4. VAT applied and excise tax collected by Customs Service of Lithuania. Source: Ministry of Finance of the Republic of Lithuania. Annual consolidated financial statements. (2007-2013)

In 2007 the Customs Service of the Republic of Lithuania collected $25.3 \%$ of the total VAT collected by the state while in 2013, the VAT collected by customs service had fallen below $7.1 \%$ of the total VAT collected by the state (Fig. 4). The principal reason behind the decline in the collection of VAT were amendments in the law on VAT, which similarly to those in Latvia provided the opportunity for the business to use the VAT deferred payment mode for the goods imported from 3rd countries. However, the excise tax collection dynamics from 2007 to 2013 was in the range of $1.9 \%-2.8 \%$ and was characterised as steadily low in relation to the total amount of excise tax collected in Lithuania. The reason for such low percentage relation of the excise tax collected was the deferred tax payment for the excise goods to be imported by dispatching them for holding in the excise goods warehouses.

In contrast, the difference between the applied and the collected VAT by the Estonian Tax and Customs Board and payments did not exceed $1 \%$, because Estonia did not have special conditions for payments of VAT for goods to be imported from 3rd countries. However, upon evaluating the VAT amount in the period of time from 2007 to 2013, one may identity a decrease in the amount of payment in relation to the total amount of VAT collected by the state from $23 \%$ in 2007 to $14.2 \%$ in 2013 (Fig. 5). While the decrease of the excise tax collection in the given time period was at $5.5 \%$ (from $7.7 \%$ to $2.2 \%$ ).

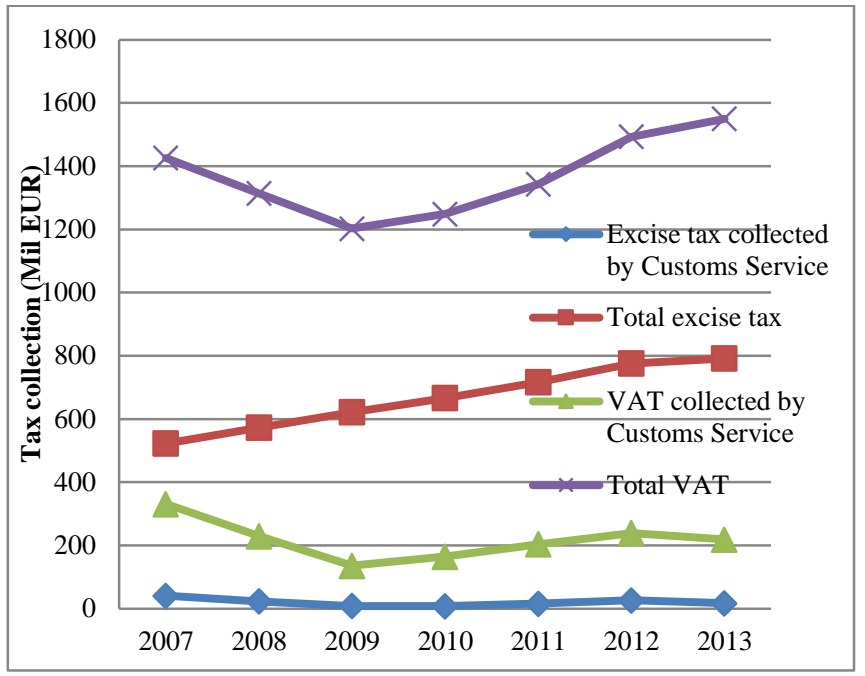

Fig. 5. VAT applied and excise tax collected by Customs Service of Estonia. Source: Estonian Tax and Customs Board. Statistics. (2007-2013)

This situation can be explained by the overall trends in the EU Customs Union - to reduce the administrative burden at the external borders of the EU, to speed up the flow of goods, thereby facilitating international trade. Unpaid customs duty on the border should not create a fiscal burden on the nature of the business; it should require compliance with various formalities, for example, customs authorities accept only the payment of taxes, where the money has come into the customs accounts. Therefore reducing the burden of customs functions may help to decrease the overall administrative burden created by customs service.

\section{CONCLUSION}

1. Accurate definition of customs functions and content as well as the determination of mutual interaction is the entry point and the basic element for the development of an assessment system because a customs service that is capable of quality performance of the functions delegated to it by the state is considered to be an effectively operating customs service.

2. The existing external (political, economic, social and technological) conditions as well as internal conditions (resources, processes and culture) influence the topicality of customs functions and task.

3. Considering the effect of globalisation, in Latvia in order to decrease the administrative load of companies and increase the operational efficacy and competitiveness thereof in the global market, a number of easements have been implemented in the payment procedure of tax administrated by customs (VAT and excise), in the meantime, simplifying tax administration and improving the status in the combat of tax evasion. 
4. Upon summary of statistical information, a clear tendency can be detected - after the accession of Latvia to the tax union of the EU from 2005 - 2014 the importance of the fiscal function performed by customs in the context of state's total budgetary revenue has substantially decreased. During this time, the collection of VAT has decreased from $29.3 \%$ to $4.3 \%$, while the amount of the excise tax collection from 2007-2014 has decreased from $63 \%$ to $0.7 \%$.

5. The contribution of customs in the application of administrated tax is still important. In Latvia, Customs Service applies $25 \%$ of the total VAT and excise tax collected by the state.

6. Easements in the payment procedure of the excise tax upon transporting goods over the customs border have been implemented in the national legislation of both Lithuania and Estonia, thus on average in 2013, customs services collected $2.2-2.8 \%$ from the total excise tax collected by the respective state, while VAT payment easements upon import of goods were implemented in Lithuania in 2007-2013, VAT collection has reduced respectively from $25.3 \%$ to $7.1 \%$.

7. The trends in the change of customs' fiscal functions set the necessity for customs services to review their strategic priorities and the division of resources as well as in order to maintain the voluntary compliance of companies with the requirements of regulatory acts at a high level, it is necessary to improve the cooperation mechanisms of customs and tax administration at the same time reducing the administrative load and on the basis of risk analysis maintaining efficient development control system.

\section{REFERENCES}

Adomaviciute, D. (2013) Customs Role Ensuring Revenue Collection. European International Journal of Science and Technology, ISSN:2304-9693.

Andrejeva, V., Ketners, K., Valsts ieṇēmumu teorijas pamati, 56.p., RTU, Rīga, 2008.

Baramzin, S.V. Upravleniye kachestvom tamozhennoy deyatelnostiyu. 2001. Moskva. s.169-176.

Chevers, A. (2013) Definitions of customs functions in the contex of economic integration and Globalization. Customs Scientific Journal CUSTOMS. ROCB \& RTCs European Region, no. 2.

Dišlers, K. Ievads administratīvo tiesību zinātnē. Tiesu nama aǵentūra, 2002., 246 lpp.

Gulbis, A., Čevers, A. “Muitas darbības pamati” RTU, Rīga, 2010., 27.-31. lpp.

Keen, M. (2003). Changing Customs: Challenges and Strategies for the Reform of Customs Administration. Washington, D.C: International Monetary Fund.
Komisijas ziṇojums padomei un Eiropas parlamentam. Septītais zinojums saskan̄ā ar 12. pantu Regulā (EEK, Euratom) Nr. 1553/89 par PVN iekasēšanu un kontroles procedūrām. Brisele, 2014.,COM(2014)69 final

Kosenko, V.P., Oposhnyan L.I. Osnovy teorii effektivnosti tamozhennogo dela M.: RTA, 2006.

Lane, M. (1998). Customs Modernization and the International Trade Superhighway. Westport, Conn.: Quorum Books.

Report concerning Special Report No 13/2011 of the Court of Auditors entitled 'Does the control of customs procedure 42 prevent and detect VAT evasion?' (C7-0019/2012 - 2012/2010(DEC)) 18.12. 2012.

State Revenue Service of the Republic of Latvia. Statistics and performance results. Retrieved: https://www.vid.gov.lv/default.aspx?tabid=11\&id=52\&hl=1 Access: 02.09.2014

Estonian Tax and Customs Board, Statistics. (2007 -2013) Retrieved: http://www.emta.ee/index.php?id=14183 Access: 02.09.2014.

Ministry of Finance of the Republic of Lithuania. Annual consolidated financial statements. (2007-2013) Retrieved: http://www.finmin.lt/ finmin.lt/failai/Turto_valdymo_departamentas/Konsolid_ataskaitos/V alstybes.PDF. Access: 02.09.2014.

Widdowson, D. (2007) The Changing World of Customs: Evolution or Revolution. World Customs Journal. Volume 1, Number 1, March, pp. 31-37.

de Wulf, L. \& Sokol, J.B. (2004). Customs Modernization Initiatives: Case Studies. Washington, D.C.: World Bank.

PADOMES REGULA (EEK) Nr. 2913/92 (1992. gada 12. oktobris) par Kopienas Muitas kodeksa izveidi, Retrieved: http://eurlex.europa.eu/legal.content/LV/TXT/HTML/?uri=CELEX:31992R29 $13 \&$ qid $=1404976235927 \&$ from $=$ LV

International Convention on the Simplification and Harmonization of Customs Procedures (The Revised Kyoto Convention), Retrieved: http://www.wcoomd.org/en/topics/facilitation/instrument-andtools/conventions/pf_revised_kyoto_conv/kyoto_new.aspx

Grozījumi likumā Par pievienotās vērtības nodokli, 22.10.2009., spēkā no 01.12.2009. Retrieved: http://likumi.lv/doc.php?id=200328

Normunds Rudzītis received the Master degree in Tax and Customs Management in 2006 from Riga Technical University and the Master degree in Engineering in 1983 from Riga Politechnical Institute. He has also received a professional degree in Economics and Accounting from the University of Latvia. He has been Director General of JSC "Imanta" (1993-1997) and from 1997 to 2012 he worked at the State Revenue Service of the Republic of Latvia (SRS). He was Director of Administrative Board of SRS from 2011 to 2012. From 2012 he is a practical senior lecturer with International Business and Customs Institute of Riga Technical University. His main research fields are Customs Management, Risk Management and Supply Chain Security issues. He has participated in a number of research projects in Eastern Europe and Central Asia and has publications in this field.

E-mail: Normunds.Rudzitis@rtu.lv

Aldis Čevers received the Master degree in Law in 2002 from the University of Latvia. 1991-2008 he was a lecturer with the Faculty of Law of the University of Latvia. From 1997 to 2002 he was Head of division of the Customs Board of the State Revenue Service of the Republic of Latvia. From 2002 he has been a practical senior lecturer with International Business and Customs Institute of Riga Technical University. His main research fields are Customs Law, EU Law, International Trade Law, Customs Organisation and Evaluation. He has written a number of textbooks and publications in this field. From 2007 he has been a member of scientific advisory council and researcher of International Business and Customs Institute, RTU.

E-mail: Aldis.Cevers@rtu.lv 